\title{
THE EFFECTIVENESS OF EXTENSIVE READING APPROACH TO IMPROVE STUDENTS' READING COMPREHENSION
}

\author{
Andi Hidayat $^{1}$, Anita Nurinayah ${ }^{2}$ \\ ${ }^{1}$ IKIP Siliwangi \\ ${ }^{2}$ IKIP Siliwangi \\ ${ }^{1}$ Andyh6558@gmail.com, ${ }^{2}$ anitanurinayah@gmail.com
}

\begin{abstract}
This research entitled the effectiveness of extensive reading approach has a purpose to figure out the effectiveness of extensive reading approach to improve students' reading comprehension. The subject of this research is students of SMK Al-Irsyad Cipanas. The sample of this research consists 20 of the eleventh grade students of AP class. The research uses quantitative research, or more specifically the one group pre-test post-test design as research design. To collect the data, this research applies pre-test and post-test as the instrument. The result of data is obtained by using t-test formula. The result showed that students who learning using extensive reading approach had better reading ability to comprehend the text. The result of tobs is 2.08, the ttable with degrees of freedom (df) 19 and level of significance at 0.05 was 1,72 . Based on the data analysis, the alternative hypothesis in this research was accepted because tobs is higher than ttable $(2.08>1.72)$. Based on the data analysis, it is found that the test is reliable. The findings indicated that learning using extensive reading approach is significantly affected the students' reading comprehension. Therefore, the extensive reading is suitable for improving students' reading comprehension and it is also a strategy that can be used by teacher for making learning process to be more effective.
\end{abstract}

Keywords: Reading Comprehension, Extensive Reading

\section{INTRODUCTION}

Language is a tool which is used by the peoples to talk each other with other peoples. Every countries have their languages. Language is not only used as a tool communication, but also to deliver information. In the globalization era, the world has decided that English as the international language.

Nowadays, English is important language in which should be mastered by every people in the world because it has become the international language. They, the people in this world also aware of the importance to learn the English language, especially for some students.

That is why, now English is formally taught from elementary until university. English has four skills, they are listening, writing, speaking and reading. One of important skill in English that we have to be mastered is reading skill. Reading is a process to develop the information. Reading also is an activity to gain the main idea or topic from the texts as well.

Mc Namara (2012: 6) states that"Reading comprehension is a cognitive or behavioral action that is enacted under particular contextual conditions, with the goal of improving some aspect

The Effectiveness Of Extensive Reading Approach To Improve Students' Reading Comprehension|1 
of comprehension." Furthermore "reading comprehension is important, not just for understanding text, but for broader learning, success in education, and employment" (E. Carsten, et.al., 2014: 1).

According to Moyle (1972) in T, Wayne (2014: 22) "reading comprehension is the skill of reading to extract knowledge or reading with understanding." From the definition above, by using good comprehension in reading skill, students can gain the information or knowledge from texts they read. Besides, good comprehension determines how far students can understand the content of the text. E. Carsten, et.al., (2014: 1) state that "Good reading comprehension will depend on good language understanding more generally."

Nowadays, reading has become a necessary. Trough reading some texts, we can gain the information that we need. Not only that, by reading, we can develop the knowledge as well.

According to Grabe and Stoller (2002: 13) there are many purposes of reading as follow:

a. Reading to search for simple information in reading to search, we typically scan the text for a specific piece of information or a specific word.

b. Reading to skim quickly

Reading to skim is a common part of many reading task and a useful skill it is won right. It involves, in essence, a combination of strategies for guessing where important information might be in the text, and then using basic reading comprehension skills on those segments of the text until a general idea is formed.

c. Reading to learn from texts

Reading to learn typically occurs in academic and professional contexts in which a person need to learn a considerable amount of information from a text

d. Reading to integrate information, write and critique texts

Reading to integrate information requires additional decisions about the relative importance of complementary, mutually supporting or conflicting information and the likely restructuring of a rhetorical frame to accommodate information from multiple sources.

According to the explanation, there are several advantages from reading which can be taken. Therefore, reading is very important for us.

As one of important skill in English, reading skill has many types and each type has certain techniques. There are types of technique in reading skill based on Kienzle, B. et.al., (2012: 20) such as:

a. Skimming

Skimming is a technique for reading comprehension that entails reading very quickly to get the general idea or gist of a passage. Skimming allows you to make inferences about the content of a particular passage, to identify the author's point of view, or to form an impression of the author's tone (happy, sad, ironic, foreboding, and so on) in order to anticipate in a general way.

b. Scanning 
Scanning is a reading comprehension technique that involves reading quickly to find specific pieces of information. You may be asked to scan a text for name of places, adjectives describing, a certain character, date and so on.

c. Close Reading

According to Brummet (2010) in C, Sunday (2012: 8) defines close reading as "the mindful, disciplined reading of an object (i.e., text) with a view to deeper understanding of its meaning." when a students engage in close reading, they analyze the text at the word or phrases level and sentence and paragraph level.

However, not every students can comprehend the text they read. There are a lot of students still have the difficulties in comprehending the text. Besides, they still lack of vocabularies and motivation to read text in English language.

To comprehend the text, learners need methods or strategies which can be used by a teacher. That strategy is used to figure out whether that strategy can improve students' reading comprehension and encourage them to read text as well.One of the strategy that writer would like to introduce is the extensive reading.

The extensive reading method is one of the strategy that can be used to comprehend the texts. "Extensive reading in the EFL/ESL context is an approach to teaching reading whose goal is to get students reading in the English language and enjoying it." (D. Richard, et.al., 2013: 2). Moreover, Palmer in R. Dana \& H, John. (2009) defines that "extensive reading as rapidly reading book after book."

According to U, Penny (2012: 146) defines that "extensive reading is the silent reading by individual students of long, interesting texts (such as stories as books). It is sometimes known as reading for pleasure or sustained silent reading (SSR). Also "Extensive reading in the EFL/ESL context is an approach to teaching reading whose goal is to get students reading in the English language and enjoying it." (D. Richard, et.al., 2013: 2).

Extensive reading is an approach that enable students to read the texts enjoyably. Besides, extensive reading also provides several benefits for students in reading as well. According to Ferdila (2016: 70) extensive reading has many benefits as following:

a. The students can choose the material that they want to read. It enable students read the text more capable.

b. To develop students' vocabulary.

c. Extensive reading involves reading widely, principally for enjoyment and for fluency rather than for mastering the target language. (Hyland, K \& Wong, L.C. 2017: 147)

d. To increase reading fluency and confidence (U, Penny. 2012: 146).

To apply extensive reading we need the steps in order the implementation of extensive reading become more reliable. The implementation of the extensive reading refer to U, Penny (2012) are:

a. Students have access to a large variety of reading material to choose from.

b. Each student choose his Or her own reading material. 
c. Students can stop reading material that they find boring or too difficult and swap it for something else.

d. The teacher encourage students to read and swap books, to help students choose, and to be a role model as a reader.

e. Students describe the content of the text they have read before.

\section{METHOD}

In this research, the writer applied research design and methodology. The research design of this research used one group pre-test post-test design. The writer conducts pre-test and posttest as the instrument of the research.

\section{One group Pre-test Post-test Design}

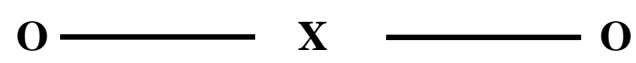

In one-group-posttest design a single group of subjects is given a pretest $(\mathrm{O})$, then the treatment $(\mathrm{X})$, and then the posttest $(\mathrm{O})$.

The writer also used quantitative research method. According to Kaswan and Suprijadi (2016: 11) define that "quantitative research design is a deductive theory-based research process that focuses primarily on testing theories and specific research hypotheses that consider finding differences and relationships using numeric data and statistical methods to make specific conclusions about phenomena."

In this research the writer used pre-test and post-test as the instruments to collect the data. The writer gave the pre-test before the writer did the treatment using the method and gave the posttest after the treatment.

To prove this research reliable or not, writer chose the research object as the evidence. The writer chose the students of SMK Al-Irsyad Cipanas, more spesifically the eleventh grade of AP class as the population. Johnson in Kaswan and Suprijadi defines that population as "the entire group of entities or persons to which the result of a study is intended to apply" (2016: $15)$.

The population in this research was the eleventh grade of AP class students of SMK Al-Irsyad Cipanas-Cianjur in the academic year 2017/2018. The population of the research consisted of 20 students.

In order to thid research more reliable, writer took the sample for the research. "Sample is the smaller group which is a portion of a population" (Tavakoli, 2012: 471). The sample of this research was the entire of the population that was eleventh grade of AP class. The number of the sample was 20 students. 
This research was conducted at SMK Al-Irsyad Cipanas in eleventh grade students of SMK AlIrsyad Cipanas-Cianjur in the academic year 2017/2018 on Jl. TK Yamin No. 01 Padarincang. The writer started the research on 4 September until 24 October 2018.

The research was applied on 6 meetings and the duration for each meeting and test were 45 minutes. In this case, the researcher tried to use one class consists of 20 students at the eleventh grade of SMK Al-Irsyad Cipanas-Cianjur in the academic year 2017/2018.

In this research, the researcher used tests to collect the data, they were pre-test and post-test. The test was given to compare the scores between experimental class and control class. The test also was given before and after the treatment. The test in this research was multiple choice tests that consisted 20 items of multiple choice questions.

\section{a. Pre-test}

Pre-test was used before the treatment to measure how far students could comprehend the text they read and to gain the score as well.

b. Treatment

The treatment in this research used extensive reading approach. The treatment was given after the pre-test.

\section{c. Post-test}

The posttest was used to determine the students' reading skill after giving the treatment. The form of the posttest was same as pretest form. The score of post-test would be compared with the score of pre-test.

To obtain the result of data analysis, writer used several formulas, they are:

\section{a. Mean Score}

According to Kaswan \& Suprijadi, D. (2016: 108) argue that "the mean is sometimes called the arithmetic mean to distinguish it from other forms of mean such as the harmonic mean or geometric mean." The formula as follows:

$$
x=\frac{\sum x}{n}
$$

\section{b. Standard Deviation}

Standard deviation is the most widely used measure of variability of a set of data in inferential statistical procedures (Kaswan \& Suprjadi. 2016: 110). The formula of standard deviation is:

$$
\mathrm{SD}=\sqrt{\frac{\Sigma D^{2}-\left(\frac{1}{n}\right)(\Sigma D)^{2}}{n-1}}
$$

\section{c. Degree of Freedom}

Degree of freedom is applied to compare between the obtained tobs with the table entry for relevant degree of freedom and level significant.The formula is:

\section{e. T-test Formula}

$$
\mathrm{df}=\mathrm{n}-1
$$


According to Kaswan \& Suprijadi (2016: 122) state that " $t$-test or students' test is a parametric test which is used to discover whether here are statistically significant differences between the means of two group." The formula is:

$$
\mathrm{t}=\frac{\bar{x}_{1}-\bar{x}_{2}}{S D}
$$

\section{CONCLUSION}

The result of the research was obtained through pre-test and post-test. Pre-test was conducted before the treatment while post-test was performed after the treatment. The result of students' pre-test and post-test as follows:

\begin{tabular}{cccccc}
\hline \multirow{2}{*}{ No } & \multirow{2}{*}{ Name } & \multicolumn{3}{c}{ Score } \\
\cline { 3 - 6 } & & Pre-test & Post-test & $\Sigma D$ & $\Sigma D^{2}$ \\
\hline 1 & Student 1 & 90 & 100 & 10 & 100 \\
\hline 2 & Student 2 & 70 & 80 & 10 & 100 \\
\hline 3 & Student 3 & 50 & 90 & 40 & 1600 \\
\hline 4 & Student 4 & 80 & 90 & 10 & 400 \\
\hline 5 & Student 5 & 60 & 80 & 20 & 400 \\
\hline 6 & Student 6 & 60 & 80 & 20 & 100 \\
\hline 7 & Student 7 & 70 & 80 & 10 & 900 \\
\hline 8 & Student 8 & 50 & 80 & 30 & 100 \\
\hline 9 & Student 9 & 80 & 90 & 10 & 400 \\
\hline 10 & Student 10 & 60 & 80 & 20 & 100 \\
\hline 11 & Student 11 & 80 & 90 & 10 & 900 \\
\hline 12 & Student 12 & 40 & 70 & 30 & 100 \\
\hline 13 & Student 13 & 70 & 80 & 10 & 400 \\
\hline 14 & Student 14 & 60 & 80 & 20 & 400 \\
\hline 15 & Student 15 & 60 & 80 & 20 & 400 \\
\hline 16 & Student 16 & 60 & 80 & 20 & 900 \\
\hline 17 & Student 17 & 80 & 90 & 10 & 900 \\
\hline 18 & Student 18 & 40 & 70 & 30 & 400 \\
\hline 19 & Student 19 & 40 & 70 & 30 & 8800 \\
\hline 20 & Student 20 & 60 & 80 & 20 & 380 \\
\hline & Total & 1420 & 1690 & & \\
\hline
\end{tabular}

Based on the data above, the result of scores was:

\section{Mean Score of Pre-test}

$x=63$

\section{Mean Score of Post-Test}

$x=82$

6 | The Effectiveness Of Extensive Reading Approach To Improve Students' Reading Comprehension 


\section{Standard Deviation Score of Pre-test}

$$
\begin{aligned}
\mathrm{SD} & =\sqrt{\frac{\Sigma D^{2}-\left(\frac{1}{n}\right)(\Sigma D)^{2}}{n-1}} \\
\mathrm{SD} & =\sqrt{\frac{8800-\left(\frac{1}{20}\right)(380)^{2}}{19}} \\
\mathrm{SD} & =\sqrt{\frac{1580}{19}}=\sqrt{83.15} \\
\mathrm{SD} & =9.12 \\
\mathrm{~T}-\text { Test } & -\bar{x} \\
\mathrm{t} & =\frac{x_{1}-x_{2}}{S D} \\
\mathrm{t} & =\frac{63-82}{9.12}=2.08
\end{aligned}
$$

The critical value of t-table with df (degree of freedom) 19 and the level of significance at 0.05 was 1.72. The t-test calculation is 2.08 . It means $t_{\text {obs }}$ is higher than $t_{\text {table }}(2.08>1.72)$.

Based on the data analysis, the alternative hypothesis in this research was accepted because $t_{\text {obs }}$ is higher than ttable $(2.08>1.72)$.

Based on the data analysis, it is found that the test is reliable. The findings indicated that learning using extensive reading approach is significantly affected the students' reading comprehension.

Therefore answering the research question, it is indeed extensive reading method proven to be quite effective in increasing student's reading comprehension.

\section{CONCLUSION}

Based on the data analysis above, the writer concluded that extensive reading approach has influenced to students reading comprehension. The Extensive Reading was effective to improve students reading ability as well. It showed from the result of $\mathrm{T}_{\mathrm{obs}}$ was higherthan the $\mathrm{t}$-table $(14.76>1.75)$ and it also means that the alternative hypothesis was accepted. However, this research still has limitation. The sample that writer uses in this research only one class. There is no control class in this research as a comparator to make the research become more reliable and valid. 


\section{ACKNOWLEDGMENTS}

The writers would like to show gratitude to Isry Laila Syatroh,M.Pd for her guidance, knowledge and patience in finishing this journal. And all faculty members of IKIP Siliwangi.

\section{REFERENCES}

Bamford \& Richard. (2013). Bringing Extensive Reading into the Classroom. London: Oxford University Press

Cummins, Sunday. (2012). Close Reading of Informational Text. New York: The Guildford Press

Dana \& John. (2009). Teaching Readers of English. Newyork: Routledge

Grabe \& Stoller. (2002) Teaching and Researching Reading. London: Pearson Education Longman

Hyland \& Lillion. (2017). Faces of English Education. New York: Routledge

Kaswan, et.al. (2016). Metode dan teknik penulisan karya ilmiah. Edisi 2 (2015) Revisi 1 (2016). Bandung: STKIP SILIWANGI Press.

Kaswan, Suprijadi. (2016).Research in English Education. Bandung: Putra Praktisi.

Kienzle, et.al. (2012). Panoramas Literarios. USA: Heinle

McNamara, S.D. (2012). Reading Comprehension Strategies: Theories, Interventions and Technologies. New York: Tayllor \& Francis Group.

Oakhill, et.al. (2015). Understanding and Teaching Reading Comprehension. London \& New York: Taylor \& Francis Group.

Penny, U. (2012). A Course in English Language Teaching. United Kingdom: Cambridge University Press.

Tennent, Wayne. (2014). Understanding Reading Comprehension: Processes and Practices. London: Sage. 